American Journal of Pharmaceutical Education 2017; 81 (7) Article 5990.

\title{
RESEARCH
}

\section{Evaluating the Changing Financial Burdens for Graduating Pharmacists}

\author{
T. Joseph Mattingly II, PharmD, MBA, ${ }^{a}$ Timothy R. Ulbrich, PharmD ${ }^{\mathrm{b}}$ \\ ${ }^{a}$ University of Maryland School of Pharmacy, Baltimore, Maryland \\ ${ }^{\mathrm{b}}$ Northeast Ohio Medical University, Rootstown, Ohio \\ Submitted August 8, 2016; accepted January 3, 2017; published September 2017.
}

Objective. To compare new practitioners in 2009 and 2014 by modeling net income from available salary, expenditure, and student loan data.

Methods. A Monte Carlo simulation with probabilistic sensitivity analysis was conducted to model net income for graduating pharmacists in 2009 and 2014. Mean and standard deviations were recorded for each model parameter. Student $t$-tests were used to compare the mean differences between 2009 and 2014 cohorts.

Results. Pharmacist salary and disposable income were higher on average in 2014 compared with 2009. Consumer expenditures were higher in 2014, offsetting the higher salary resulting in a 2014 discretionary income that was less than in 2009 [95\% CI: -\$2,336, -\$1,587]. Net income decreased from 2009 to 2014 for all pharmacy school types.

Conclusion. Regardless of loan payment strategy, net incomes for pharmacists graduating from public and private institutions were less in 2014 compared with 2009.

Keywords: student debt, new practitioners, personal finance

\section{INTRODUCTION}

The cost of attending pharmacy school in the United States and the debt incurred by new practitioners has risen substantially in recent years, providing some concern for many stakeholders. ${ }^{1}$ Combined with concerns surrounding job opportunities for new graduates, the pressure of growing student debt has sounded an alarm in the form of editorials and online discussion boards in the pharmacist community. ${ }^{2-4}$ According to the Bureau of Labor and Statistics (BLS), the average annual salary for a pharmacist increased from $\$ 106,630$ in 2009 to $\$ 118,470$ in $2014 .^{5}$ At the same time, the average amount borrowed for students graduating from pharmacy school increased from $\$ 101,892$ in 2009 to $\$ 144,718$ in $2014 .{ }^{6,7}$ The percentage of pharmacy graduates reporting that they had to borrow money to help pay for college expenses ranged from $87 \%$ to $91 \%$ between the years 2009 and 2014 . Looking further at the amount borrowed by pharmacy students attending public or private schools, those graduating from public schools reported borrowing an average amount of $\$ 85,410$ in 2009 and $\$ 120,060$ in 2014 compared to those graduating from private schools reporting an average amount borrowed of $\$ 119,784$ in 2009 and $\$ 166,534$ in 2014. ${ }^{6,7}$ Between 2009 and 2014, this

Corresponding Author: Joey Mattingly, 20 N. Pine St., N415, Baltimore, MD 21201. Tel: 410-706-8068. Fax: 410706-4725. E-mail: jmattingly@rx.umaryland.edu
$42.0 \%$ increase in the average student loan debt in pharmacy education (all schools combined) was greater than that in other health professions including medicine ( $\$ 156,456$ in 2009 to $\$ 176,348$ in $2014 ; 12.7 \%$ increase) and dentistry (\$189,678 in 2009 to $\$ 247,227$ in 2014; $30.3 \%$ increase) ${ }^{8-10}$

Similar trends regarding the rise in student loan debt in the US, regardless of the occupation, have been welldocumented. Data from The Institute for College Access \& Success note that approximately $70 \%$ of college graduates have student loan debt with an average amount owed of $\$ 28,950 .^{11}$ The amount owed grew from $\$ 18,550$ in 2004 and more than doubled the rate of inflation over that time period. ${ }^{11}$ Similarly, a study conducted by Harris Poll on behalf of NerdWallet in 2015 found the average student loan debt for those households with that type of debt was $\$ 48,172$. Furthermore, it was estimated to be $\$ 1.23$ trillion owed in student loans by US consumers. ${ }^{12}$

While pharmacist salaries have increased at a rate similar to that of tuition increases as documented by Cain and colleagues, ${ }^{1}$ the annual salary of a pharmacist continues to be less in recent years in relation to overall student indebtedness. For example, in 2015, the average pharmacist salary was $\$ 119,270$ with an average amount borrowed for a graduate in the class of 2015 of $\$ 149,320 .^{5,13}$ This salary to debt ratio of .80 is lower than that in 2011 (.98), the first year the ratio fell below 1.0. ${ }^{1}$ 


\section{American Journal of Pharmaceutical Education 2017; 81 (7) Article 5990.}

The complexity of this upward trend regarding student debt spans from student-level issues such as loan eligibility, interest rates, student personal finance knowledge, to pharmacy school-level factors such as facilities and increased administrative costs to educate students. ${ }^{14}$

With student loan debt outpacing gains in income for pharmacy graduates, the question has been raised as to whether a pharmacy education has a positive return on investment. More specifically, how much, if any, has that return on investment changed with these recent trends in rising student loan debt? Chisholm-Burns and colleagues used Markov modeling to evaluate the value of a pharmacy education and associated costs on net career earnings. Despite rising indebtedness, this study concluded that obtaining a doctor of pharmacy degree does produce a favorable return on investment. ${ }^{15}$ While this study evaluated the net career earnings of the pharmacist, it did not evaluate the change in net income available to a pharmacist per month and how this may have changed in the past several years. While the return on investment of a pharmacy education and career was shown to be favorable compared to that of someone with a high school diploma or a bachelor's degree in biology or chemistry, it can be assumed that the return on investment of the pharmacy degree weakens as student indebtedness grows at a faster pace than does a pharmacist's salary.

Economists traditionally view education in the form of a financial investment which allows for measuring the return on investment for pursuing an additional degree in monetary terms. This technique has also been applied to pharmacy degrees demonstrating positive returns for graduates despite rising initial investment costs. ${ }^{1,15-17}$ This study aims to compare private financial returns for new practitioners in 2009 and 2014 by modeling net income from available salary, consumer expenditure, and student loan data.

\section{METHODS}

A Monte Carlo simulation was conducted to model net income for graduating pharmacists in 2009 and 2014. Disposable income and discretionary income were defined by methods described by the Bureau of Economic Analysis (BEA). ${ }^{18}$ A conceptual model was developed to define net income for graduating pharmacists as discretionary income less student loan expenses (Figure 1) to further demonstrate the financial position of the average pharmacist.

Multiple data sources were used to obtain parameter information for hypothetical pharmacy school graduate cohorts for 2009 and 2014 (Table 1). Pharmacist annual salary information was obtained from the Occupational Employment Statistics (OES) program of the Bureau of

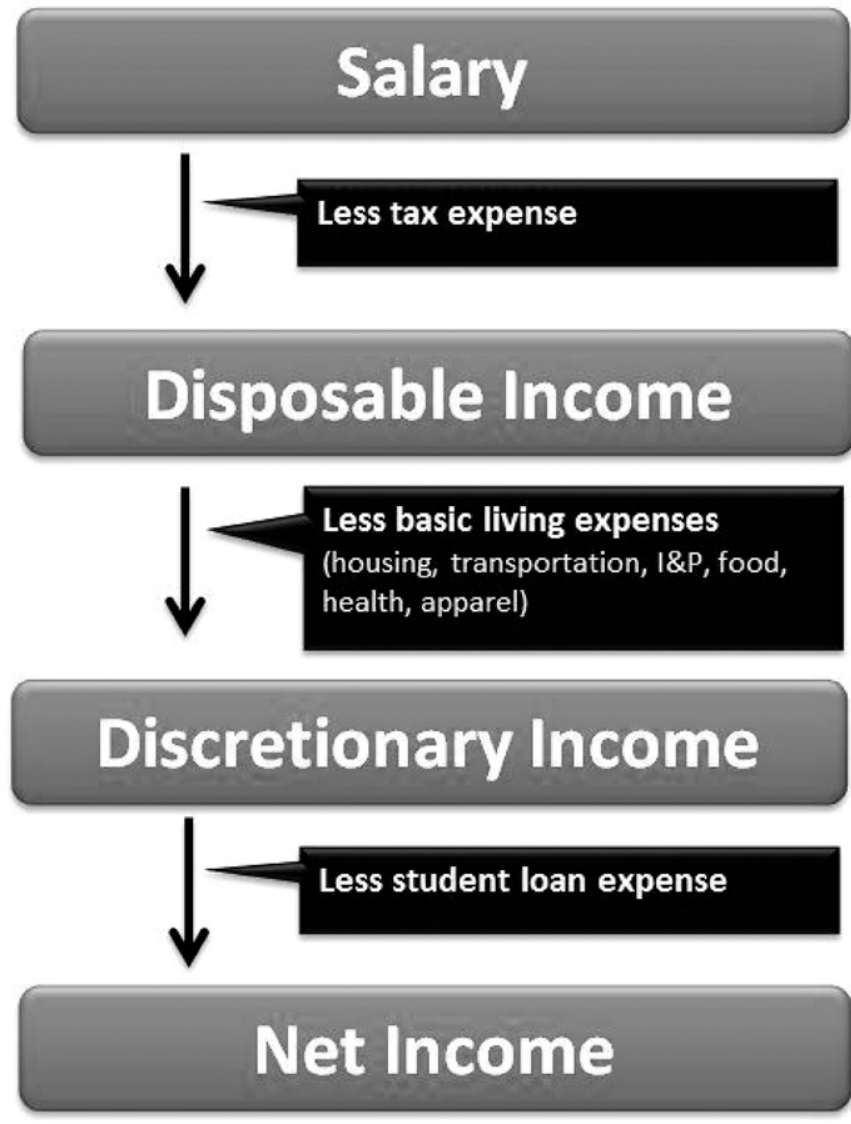

Figure 1. Personal Finance Model of Net Income After Student Loan Expenditures.

Labor Statistics (BLS). ${ }^{5}$ A time value of money discount rate of $1.5 \%$ was used to adjust 2009 salary in terms of 2014 dollars. ${ }^{17,19}$ Living expense information was obtained from the BLS Consumer Expenditure Survey (CES) annual expenditure means, shares, standard errors, and coefficients of variation tables for 2009 and $2014 .^{20}$

Student loan burden was obtained by school type from the American Association of Colleges of Pharmacy (AACP) graduating student survey summary reports. ${ }^{21}$ Because these surveys contained total debt, annual expenditure estimates for student debt were calculated using an interest rate of $5.5 \%$ over both 10 and 25 years and stratified by school type.

Probabilistic sensitivity analysis (PSA) was used to handle uncertainty with each of the deterministic parameter estimates by assigning distributions (Table 1) and conducting 1,000 trials using a visual basic macro in Microsoft Excel (Redmond, WA). ${ }^{22}$ Gamma distributions were chosen for salary and debt inputs and beta distributions were assigned to binomial consumer expenditure inputs. Mean and standard deviations were recorded for each model parameter. Student $t$-tests were used to compare the mean differences between 2009 and 2014 
American Journal of Pharmaceutical Education 2017; 81 (7) Article 5990.

Table 1. Model Parameters for Monte Carlo Simulation

\begin{tabular}{|c|c|c|c|c|c|c|c|}
\hline Variable & Description & $\begin{array}{l}\text { Deterministic } \\
\text { Parameter }\end{array}$ & $\begin{array}{c}\text { Standard } \\
\text { Error }\end{array}$ & Distribution & Alpha & Beta & References \\
\hline \multicolumn{8}{|l|}{ Salary Inputs } \\
\hline RPhSalary_09 & Salary for 2009 & 106630 & 13959 & Gamma & 58.35 & 1827.38 & 5 \\
\hline RPhSalary_14 & Salary for 2014 & 118470 & 14872 & Gamma & 63.46 & 1866.94 & 5 \\
\hline \multicolumn{8}{|c|}{ Consumer Expenditures } \\
\hline Exp_tax & $\%$ income for tax & .13 & .00183 & Beta & 4390.27 & 29381.02 & 20 \\
\hline Exp_09_house & $\begin{array}{l}\% \text { for housing in ' } 09 \text { for } \\
\$ 108 \mathrm{k} \text { income }\end{array}$ & .22 & .00380 & Beta & 2608.40 & 9247.98 & 20 \\
\hline Exp_14_house & $\begin{array}{l}\% \text { for housing in ' } 14 \text { for } \\
\$ 108 \mathrm{k} \text { income }\end{array}$ & .222 & .00390 & Beta & 2523.24 & 8842.69 & 20 \\
\hline Exp_09_auto & $\begin{array}{l}\% \text { for transportation in ' } 09 \text { for } \\
\$ 108 \mathrm{k} \text { income }\end{array}$ & .114 & .00648 & Beta & 274.49 & 2133.31 & 20 \\
\hline Exp_14_auto & $\begin{array}{l}\% \text { for transportation in ' } 14 \text { for } \\
\$ 108 \mathrm{k} \text { income }\end{array}$ & .127 & .00635 & Beta & 348.78 & 2397.51 & 20 \\
\hline Exp_09_ins & $\begin{array}{l}\% \text { for pension/insurance in } \\
\text { '09 for } \$ 108 \mathrm{k} \text { income }\end{array}$ & .099 & .00296 & Beta & 1009.98 & 9191.87 & 20 \\
\hline Exp_14_ins & $\begin{array}{l}\% \text { for pension/insurance in } \\
\text { '14 for } \$ 108 \mathrm{k} \text { income }\end{array}$ & .097 & .00237 & Beta & 1510.10 & 14057.95 & 20 \\
\hline Exp_09_food & $\begin{array}{l}\% \text { for food in ' } 09 \text { for } \$ 108 \mathrm{k} \\
\text { income }\end{array}$ & .089 & .00245 & Beta & 1201.92 & 12302.77 & 20 \\
\hline Exp_14_food & $\begin{array}{l}\% \text { for food in ' } 14 \text { for } \$ 108 \mathrm{k} \\
\text { income }\end{array}$ & .088 & .00214 & Beta & 1539.10 & 15950.63 & 20 \\
\hline Exp_09_health & $\begin{array}{l}\% \text { for health in ' } 09 \text { for } \$ 108 \mathrm{k} \\
\text { income }\end{array}$ & .04 & .00166 & Beta & 558.71 & 13409.05 & 20 \\
\hline Exp_14_health & $\begin{array}{l}\% \text { for health in ' } 14 \text { for } \$ 108 \mathrm{k} \\
\text { income }\end{array}$ & .054 & .00143 & Beta & 1341.08 & 23493.71 & 20 \\
\hline Exp_09_apparel & $\begin{array}{l}\% \text { for apparel in ' } 09 \text { for } \$ 108 \mathrm{k} \\
\text { income }\end{array}$ & .024 & .00167 & Beta & 202.23 & 8223.83 & 20 \\
\hline Exp_14_apparel & $\begin{array}{l}\% \text { for apparel in ' } 14 \text { for } \$ 108 \mathrm{k} \\
\text { income }\end{array}$ & .023 & .00144 & Beta & 248.06 & 10537.06 & 20 \\
\hline \multicolumn{8}{|c|}{ Student Loan Total Debt } \\
\hline Debt_09_all & $\begin{array}{l}\text { Total student debt for all } \\
\text { schools in ' } 09\end{array}$ & 101,892 & 63,039 & Gamma & 2.61 & 39001.25 & 6 \\
\hline Debt_14_all & $\begin{array}{l}\text { Total student debt for all } \\
\text { schools in ' } 14\end{array}$ & 144,718 & 78,530 & Gamma & 3.40 & 42613.64 & 7 \\
\hline
\end{tabular}


American Journal of Pharmaceutical Education 2017; 81 (7) Article 5990.

Table 1. (Continued)

\begin{tabular}{|c|c|c|c|c|c|c|c|}
\hline Variable & Description & $\begin{array}{l}\text { Deterministic } \\
\text { Parameter }\end{array}$ & $\begin{array}{c}\text { Standard } \\
\text { Error }\end{array}$ & Distribution & Alpha & Beta & References \\
\hline Debt_09_public & $\begin{array}{l}\text { Total student debt for public } \\
\text { schools in '09 }\end{array}$ & 85,410 & 58,840 & Gamma & 2.11 & 40535.60 & 6 \\
\hline Debt_09_private & $\begin{array}{l}\text { Total student debt for private } \\
\text { schools in ' } 09\end{array}$ & 119,784 & 62,576 & Gamma & 3.66 & 32690.14 & 6 \\
\hline Debt_14_public & $\begin{array}{l}\text { Total student debt for public } \\
\text { schools in ' } 14\end{array}$ & 120,060 & 66,151 & Gamma & 3.29 & 36448.07 & 7 \\
\hline Debt_14_private & $\begin{array}{l}\text { Total student debt for private } \\
\text { schools in ' } 14\end{array}$ & 166,534 & 82,076 & Gamma & 4.12 & 40451.02 & 7 \\
\hline
\end{tabular}

cohorts. All statistical analyses were done in Microsoft Excel and the full model was submitted as supplemental material with the manuscript.

\section{RESULTS}

In terms of 2014 dollars, pharmacist salary and disposable income were higher on average in 2014 when compared with 2009 (Table 2). Consumer expenditures were higher in housing, transportation, food, and health in 2014. There was no difference in expenditures on insurance and pension or apparel from 2009 to 2014. Total expenditures were \$5,088 [95\% CI: \$4,274, \$5,902] higher in 2014, offsetting the higher salary resulting in a 2014 discretionary income that was less than in 2009 [95\% CI: $-\$ 2,336,-\$ 1,587]$.

Net income decreased from 2009 to 2014 for graduates of both public and private pharmacy schools (Table 3 ). The 25-year repayment term option increases net income across the board, but 2014 graduates still earned less net income when compared to the 2009 cohort across all school types.

\section{DISCUSSION}

This analysis of new practitioner net income confirms previous work regarding the challenges graduates face with student debt. Cain and colleagues determined the cost of pharmacy school along with student indebtedness increased substantially from 2008 to 2012, while Chisholm-Burns and colleagues found similar results regarding average debt loads of pharmacy school graduates compared to those who graduate with undergraduate degrees. ${ }^{1,17}$ Our model further explains how total debt impacts the amount of money new practitioners actually have to put in the bank after factoring in basic consumer and student loan expenditures.

Pharmacist salaries have risen substantially over the span of the past two decades, but there may be some concern with slowed growth or potentially lower salaries

Table 2. Comparison of Model Estimates for 2014 and 2009 Graduates

\begin{tabular}{lccc}
\hline & 2014 Mean (SD) & 2009 Mean (SD) & Mean Difference [95\% CI] \\
\hline Salary $^{\mathrm{b}}$ & $\$ 118,784(\$ 15,058)$ & $\$ 115,191(\$ 15,092)$ & $\$ 3,593[\$ 2,246, \$ 4,939]^{\mathrm{a}}$ \\
$\quad$ Tax Expense & $\$ 15,434(\$ 1,968)$ & $\$ 14,968(\$ 1,973)$ & $\$ 466[\$ 291, \$ 642]^{\mathrm{a}}$ \\
Disposable Income & $\$ 103,350(\$ 13,104)$ & $\$ 100,223(\$ 13,132)$ & $\$ 3,126[\$ 1,955, \$ 4,298]^{\mathrm{a}}$ \\
$\quad$ Housing Expense & $\$ 26,381(\$ 3,380)$ & $\$ 25,356(\$ 3,375)$ & $\$ 1,025[\$ 723, \$ 1,327]^{\mathrm{a}}$ \\
$\quad$ Transportation Expense & $\$ 15,091(\$ 2,084)$ & $\$ 13,091(\$ 1,862)$ & $\$ 1,999[\$ 1,823, \$ 2,176]^{\mathrm{a}}$ \\
Insurance \& Pension Expense & $\$ 11,509(\$ 1,482)$ & $\$ 11,423(\$ 1,549)$ & $\$ 86[-\$ 50, \$ 221]$ \\
Food Expense & $\$ 10,454(\$ 1,326)$ & $\$ 10,252(\$ 1,386)$ & $\$ 202[\$ 80, \$ 325]^{\mathrm{a}}$ \\
Health Expense & $\$ 6,412(\$ 826)$ & $\$ 4,604(\$ 622)$ & $\$ 1,808[\$ 1,743, \$ 1,873]^{\mathrm{a}}$ \\
$\quad$ Apparel & $\$ 2,735(\$ 389)$ & $\$ 2,768(\$ 415)$ & $-\$ 32[-\$ 68, \$ 3]$ \\
Total Consumer Expenditures & $\$ 72,582(\$ 9,288)$ & $\$ 67,494(\$ 8,939)$ & $\$ 5,088[\$ 4,274, \$ 5,902]^{\mathrm{a}}$ \\
Discretionary Income & $\$ 30,768(\$ 4,009)$ & $\$ 32,703(\$ 4,370)$ & $-\$ 1,962[-\$ 2,336,-\$ 1,587]^{\mathrm{a}}$ \\
\hline
\end{tabular}

${ }^{\text {a Statistically significant at } p<.05}$

b2009 amounts reported in 2014 dollars with $1.5 \%$ annual discount rate 


\section{American Journal of Pharmaceutical Education 2017; 81 (7) Article 5990.}

Table 3. Comparison of Net Incomes Between 2014 and 2009 Pharmacy School Graduates Stratified by Repayment Term and School Type

\begin{tabular}{|c|c|c|c|}
\hline & 2014 Mean (SD) & 2009 Mean (SD) & Mean Difference $[95 \% \mathrm{CI}]$ \\
\hline \multicolumn{4}{|c|}{ 10-Year Loan Repayment Term } \\
\hline \multicolumn{4}{|c|}{ Net Income } \\
\hline All & $\$ 12,154(\$ 10,858)$ & $\$ 19,345(\$ 9,544)$ & $-\$ 7,190[-\$ 8,110,-\$ 6,271]^{\mathrm{a}}$ \\
\hline Public Schools & $\$ 15,260(\$ 9,034)$ & $\$ 21,774(\$ 8,741)$ & $-\$ 6,514[-\$ 7,294,-\$ 5,733]^{\mathrm{a}}$ \\
\hline Private Schools & $\$ 9,481(\$ 11,170)$ & $\$ 17,387(\$ 9,599)$ & $-\$ 7,905[-\$ 8,809,-\$ 7,002]^{\mathrm{a}}$ \\
\hline \multicolumn{4}{|c|}{ 25-Year Loan Repayment Term } \\
\hline \multicolumn{4}{|c|}{ Net Income } \\
\hline All & $\$ 20,236(\$ 6,975)$ & $\$ 25,156(\$ 6,572)$ & $-\$ 4,920[-\$ 5,533,-\$ 4,307]^{\mathrm{a}}$ \\
\hline Public Schools & $\$ 21,993(\$ 6,081)$ & $\$ 26,530(\$ 6,116)$ & $-\$ 4,538[-\$ 5,073,-\$ 4,002]^{\mathrm{a}}$ \\
\hline Private Schools & $\$ 18,723(\$ 7,092)$ & $\$ 24,048(\$ 6,566)$ & $-\$ 5,325[-\$ 5,917,-\$ 4,733]^{\mathrm{a}}$ \\
\hline
\end{tabular}

${ }^{\text {aStatistically significant at } p<.05}$

compared to expected salaries based on recent trends. ${ }^{1,23,24}$ Cain and colleagues found that while pharmacists' salaries were higher comparing 2011 to 2002, they noticed that 2011 salaries were actually $\$ 3,064$ below the predicted mean. ${ }^{1}$ Additionally, they included indebtedness trends for physicians and dentists for comparison and observed that the ratio of salary to indebtedness for pharmacy graduates decreased the most, increasing the opportunity costs of attending pharmacy school over other similar health profession paths. ${ }^{1}$ Our model found that when comparing mean salaries adjusted for a $1.5 \%$ inflation rate, pharmacists made $\$ 3,593$ more in 2014 compared to 2009 . However, our model only considered total salary reported by BLS data, which may be impacted by other variables such as fulltime vs part-time employment or other individual-level factors. $^{25,26}$

Basic consumer expenditures between 2009 and 2014 cohorts increased along with the increase in salary, which can be explained to some extent by the model. Since expenditures are estimated as a proportion of salary, one would expect if pharmacist salaries increase, a comparable increase in expenditures would be observed. However, total consumer expenditures increased faster than salary resulting in a less favorable discretionary income for 2014 graduates. Transportation and health expenditures saw the largest increases from 2009 to 2014, driving $75 \%$ of difference between the two groups. Health care costs changes in the United States have been well documented and projected future spending does not appear to slow down, so this increase in our model could have been expected. ${ }^{27}$ Increased spending on transportation could be a result of a variety of individual choices or potentially national-level factors from fuel prices, availability of public transportation, or urban sprawl increasing private transportation costs. ${ }^{28,29}$ While the profession of pharmacy may have little influence on oil prices, individual pharmacists do have control over decisions regarding automobile purchases or proximity of home to work.

The difference in net income available to a pharmacist in 2014 compared to 2009 is noteworthy. The simulations from this study show that a pharmacist graduating in 2014 opting in to the 10-year loan repayment has a net income available that is on average $\$ 7,190$ less than a 2009 graduate. This difference equates to approximately $\$ 600$ per month. Assuming this money could be used for paying down loans at a faster rate, saving for retirement or achieving other financial goals, the difference warrants further discussion. For example, saving $\$ 600$ per month throughout one's working career (40 years) earning 6\% growth would result in over $\$ 1.1$ million. If instead, a pharmacist chose to utilize that $\$ 600$ of net income to pay beyond the minimum payment on his/her student loans that would result in significant savings of interest and a faster time period of paying off the loan. For example, if a pharmacist graduates with $\$ 150,000$ of student loan debt at $6 \%$ interest and opts in to the standard 10-year repayment plan, he/she would pay a total of $\$ 199,837$ after the 10 years $(\$ 150,000$ loan principal plus $\$ 49,837$ in interest). If instead, he/she could pay $\$ 600$ extra per month utilizing the additional net income available, he/ she would pay a total of $\$ 182,629$ ( $\$ 150,000$ loan principal plus $\$ 32,629$ in interest) with a pay off period of just over six years. That is approximately $\$ 17,000$ of interest saved by paying off the loan four years earlier. Many may argue that pharmacists wouldn't use this additional net income for paying down debt and/or saving for retirement but rather spend that money on other expenses (eg, discretionary expenses such as eating out, car purchases, buying a bigger home, etc.). That highlights the need for further education for students and pharmacists on how to better manage their personal finances. 


\section{American Journal of Pharmaceutical Education 2017; 81 (7) Article 5990.}

Colleges of pharmacy should consider adding coursework (required or elective) that helps educate students appropriately on managing their finances. Based on the findings in this study, topics such as managing debt and accounting for monthly expenses would be most meaningful to help increase a pharmacist's net income. Several colleges of pharmacy have personal finance electives available to students including Midwestern University College of Pharmacy-Glendale (PPRAG 1348: Personal Finance for the Health Care Professional), University of Hawaii at Hilo Daniel K. Inouye College of Pharmacy (PHFF 557: Personal Finance), University of Arkansas for Medical Sciences (PhPr 5702: Personal Finance), South Carolina College of Pharmacy (SCCP 764: Personal Finance), and Northeast Ohio Medical University College of Pharmacy (Personal Finance for the Student Pharmacist). Chui's article further describes the elective course at Midwestern University College of PharmacyGlendale. $^{30}$ This 15 -hour elective course covered financial goal setting, budgeting, managing debt, purchasing a home, tax considerations, insurance needs, retirement savings, investing and job selection. In additional to high student satisfaction with the material, students' financial literacy improved as measured by the Jump\$tart Financial Literacy Survey. ${ }^{30}$ Further research is needed to see if participation in a course such as the one offered at Midwestern University impacts the management of personal finances after graduation.

While personal finance education may positively impact future decision making, depending on the timing of that education and the readiness of the student to adopt good financial habits, significant indebtedness and poor financial decision making may have already occurred during undergraduate coursework and/or in the early years of pharmacy education. Therefore, a longitudinal approach to personal finance education in the K-12, postsecondary and graduate education levels are needed. Consistent reinforcement of basic financial principles is necessary. At a minimum, pharmacy schools should focus on maximizing educational opportunities as soon as students are accepted to the program and begin to matriculate into the Doctor of Pharmacy curriculum. This education should be longitudinal across all professional years where a student's financial interest and situation may change as the transition to becoming a graduate gets closer.

In addition to offering personal finance education in the PharmD curriculum, faculty and administrators within the college should work closely with the financial aid office to understand the resources available to students (eg, loan counseling) to help inform the development of those resources and to be able to refer students to those resources. Students may often raise questions about their personal finances as they are considering their career options and therefore faculty and staff involved with student career education/planning should be well-versed in the resources available to students and to refer students to those resources when needed.

In addition to expanding personal finance education in colleges of pharmacy and increasing utilization of financial aid resources available to students, other solutions must be considered. For example, the pros and cons of shorter paths to degree completion should be evaluated. Whether that be a more defined path for entry into the PharmD program or through an accelerated PharmD program, the possibility of reducing overall tuition and cost of living expenses should be weighed against challenges that may come with students pursuing an accelerated path to a pharmacy degree. These challenges may include poor student progression and retention, a student's inability to live a balanced life and be mentally healthy while taking a compact course load, and the student's inability to find time to complete work experiences while in school.

To minimize student indebtedness and/or the amount he/she must repay, pharmacy schools should evaluate the promotion of career paths in public or rural health or other qualifying employers where loan forgiveness and reduction programs exist. For example, the public student loan forgiveness (PSLF) program forgives borrowers of certain federal loans of any balance due after making 120 consecutive payments while working for a qualifying employer. Depending on the students' indebtedness, adjusted gross income, interest rate of loans borrowed and family structure, the amount forgiven can be significant. Since qualifying employers include government organizations, non-profit organizations that are tax-exempt under Section 501(c)(3) of the Internal Revenue Code and the AmeriCorps or Peace Corps, a significant number of graduates (most notably those pursuing employment in non-profit hospital) are eligible for the PSLF.

The main factor resulting in the decreased net income available for a pharmacist from 2009 to 2014 is student debt load. Therefore, in addition to the efforts noted above, pharmacy schools should consider ways to limit student debt by increasing scholarships available to students, minimizing tuition raises, and encouraging students to minimize the amount of money borrowed with student loans to cover cost of living expenses.

Salary data utilized in this model reflects the aggregate pharmacist salary information in the BLS which does not reflect differences in practice areas, geographic regions, or years of practice. This source of salary information was chosen for consistency with previous published models that include pharmacist salary. ${ }^{1,15,17}$ Additionally, consumer expenditures were analyzed as an aggregated 


\section{American Journal of Pharmaceutical Education 2017; 81 (7) Article 5990.}

amount which would reflect the cost of living adjustments across regions. Student debt assumptions were derived from graduating student surveys with a response rate around $70 \%$, also a shared source with previous studies. There is limitation with using the median and average debt load numbers associated with the AACP graduating student survey. The most notable limitation is in how the question is asked and therefore impacts the reliability of the data. For example, in the 2014 AACP Graduating Student Survey, graduates were asked the following question: "Have you borrowed money to help pay for your college expenses in the Pharm.D. degree program." The 2009 and 2010 survey did not specify borrowing specific to the "Pharm.D. degree program." Therefore, respondents from 2009 and 2010 surveys and those in more recent years that did not read the question carefully could have included a total student loan balance including expenses from any undergraduate coursework.

In addition to the limitations of how the student loan debt numbers are gathered in the survey, there are external factors that may contribute to changes in the debt load among graduates over time that are not captured within the AACP Graduating Student Survey. These would include, but are not limited to, factors such as the proportion of private and public universities, the prevalence of student scholarships, availability of work-study jobs and paid internships, proportion of in-state vs out-of-state enrolled students, availability of family financial support, and graduates' plans to participate in loan forgiveness and reduction programs (eg, public student loan forgiveness program). These factors could impact the amount of student loan debt that is accrued and should be considered when discussing potential solutions for reducing student indebtedness. The PSA strategy using distributions in a Monte Carlo simulation was meant to address parameter uncertainty.

Sources for methodological uncertainty for comparing 2009 and 2014 cohorts were in the decisions around discounting for the time value of money and student loan interest rates. These values were held constant at $1.5 \%$ and $5.5 \%$ respectively. Cost-of-living adjustments of $1.5 \%$ were consistent in previous pharmacist income studies and reflect the World Bank rate of inflation in the US between 2009 and 2014, but student loan interest rates varied from $4.66 \%$ to $11 \% .{ }^{1,15,17,31}$ By maintaining a more conservative student loan interest rate value, the net income results of the present model would be more robust than a comparable model incorporating the higher interest rates observed in graduate school loans.

Additionally, the decision to compare 2009 to 2014 data was a result of the publicly available data sources used for the inputs. The AACP graduating student survey summaries were available starting in 2009 and the BLS data was as recent as 2014 during the development of the model. The recession prior to 2009 could influence the salary and consumer expenditures for that cohort, but the bias would be expected to lower those figures. Our model does not adjust for macroeconomic variables, other than inflation, but could be a future direction for analysis of pharmacists' overall standing in the US economy. Evaluation of opportunity costs of becoming a pharmacist versus other professional career choices may also be of interest to capture the impact of negative financial trends.

\section{CONCLUSION}

Salary, disposable income, and total consumer expenditures for pharmacists were higher in 2014 compared to 2009 while discretionary income was less. Regardless of loan payment strategy, net incomes for pharmacists graduating from public and private institutions were less in 2014 compared with 2009.

\section{ACKNOWLEDGMENTS}

The authors would like to thank Jamie Taylor, BA, with the American Association of Colleges of Pharmacy for assistance with the graduating student survey information.

\section{REFERENCES}

1. Cain J, Campbell T, Congdon B, et al. Pharmacy Student Debt and Return on Investment of a Pharmacy Education. Am J Pharm Educ. 2014;78(1):Article 5.

2. Barker A. The Pharmacy Job Crisis: Blame the Pharmacy School Bubble. Pharmacy Times. http://www.pharmacytimes.com/contributor/ alex-barker-pharmd/2015/05/the-pharmacy-job-crisis-blame-thepharmacy-school-bubble. Published May 26, 2015.

3. Zavadski K. The Pharmacy School Bubble is About to Burst: One of America's most reliable professions is producing too many graduates and not enough jobs. New Republic. https://newrepublic. com/article/119634/pharmacy-school-crisis-why-good-jobs-aredrying. Published September 29, 2014.

4. Bonner L. Are there enough jobs for pharmacists, or is supply and demand just leveling out? Pharmacy Today. http://www.pharmacist. com/are-there-enough-jobs-pharmacists-or-supply-and-demand-justleveling-out. Published December 1, 2014.

5. Bureau of Labor Statistics. Occupational Employment Statistics. http://www.bls.gov/oes/. Accessed January 26, 2017.

6. American Association of College of Pharmacy Graduating Student Survey: 2009 National Summary Report. http://www.aacp.org/resources/ research/institutionalresearch/Documents/2009_GSS_Summary

Report_all schools_83.pdf. Accessed June 29, 2016.

7. American Association of College of Pharmacy Graduating Student Survey: 2014 National Summary Report. http://www.aacp. org/resources/research/institutionalresearch/Documents/2014_GSS_

Final\%20Summary\%20Report_All\%20Schools_117_for\%20web.pdf. Accessed June 29, 2016.

8. Medical Student Education: Costs, Debt, and Loan Repayment Facts. October 2009. http://sls.downstate.edu/financial_aid/assistance/loans/ 


\section{American Journal of Pharmaceutical Education 2017; 81 (7) Article 5990.}

documents/AAMCOctober2009Debtfactcard.pdf. Accessed June 29, 2016.

9. Medical Student Education: Debt, Costs, and Loan Repayment Fact Card. October 2014. https://members.aamc.org/eweb/upload/ 2014\%20DFC_\%20vertical.pdf. Accessed June 29, 2016.

10. Average debt among graduating students with debt by type of school, 1996-2014 (current dollars). http://www.adea.org/data/ seniors/. Accessed June 29, 2016.

11. Student Debt and the Class of 2014. http://ticas.org/sites/default/ files/pub_files/classof2014.pdf. Accessed June 29, 2016.

12. 2015 American Household Credit Card Debt Study. Nerdwallet. https://www.nerdwallet.com/blog/credit-card-data/average-creditcard-debt-household/. Accessed June 29, 2016.

13. American Association of College of Pharmacy Graduating Student Survey: 2015 National Summary Report. http://www.aacp. org/resources/research/institutionalresearch/Documents/2015 Graduating Student Survey_Final Summary Report_All schools_for web.pdf. 14. Cain J, Campbell T, Congdon B, et al. Complex Issues Affecting Student Pharmacist Debt. Am J Pharm Educ. 2014;78(7):Article 131. 15. Chisholm-Burns MA, Gatwood J, Spivey CA. Economic analysis of obtaining a PharmD degree and career as a pharmacist. Am J Pharm Educ. 2015;79(8):Article 117. doi:10.5688/ajpe798117.

16. Oreopoulos P, Salvanes KG. Priceless: The Nonpecuniary Benefits of Schooling. J Econ Perspect. 2011;25(1):159-184. doi:10.1257/jep.25.1.159. 17. Chisholm-burns MA, Gatwood J, Spivey CA, Dickey SE. Break-Even Income Analysis of Pharmacy Graduates Compared to High School and College Graduates. Am J Pharm Educ. 2016;80(3): Article 44.

18. Landefeld JS, Moulton BR, Platt JD, Villones SM. GDP and Beyond: Measuring Economic Progress and Sustainability. Bur Econ Anal. 2009;(April):12-25.

19. Moore M a., Boardman AE, Vining AR. More appropriate discounting: the rate of social time preference and the value of the social discount rate. J Benefit-Cost Anal. 2013;4(1):1-16.

doi:10.1515/jbca-2012-0008.
20. Bureau of Labor Statistics. Consumer Expenditure Survey: Quintiles of Income Before Taxes. http://www.bls.gov/cex/csxstnd. htm. Published 2015. Accessed November 13, 2015.

21. American Association of Colleges of Pharmacy. Pharmacy Graduating Student Survey Summary Reports. http://www.aacp.org/ resources/research/institutionalresearch/Pages/GraduatingStudentSurvey. aspx. Accessed July 12, 2016.

22. Briggs A, Claxton K, Sculpher M. Decision Modelling for Health Economic Evaluation. Oxford: Oxford University Press; 2006.

23. Cooksey JA, Knapp KK, Walton SM, Cultice JM. Challenges to the pharmacist profession from escalating pharmaceutical demand. Health Aff. 2002;21(5):182-188. doi:10.1377/hlthaff.21.5.182.

24. Brown D. From shortage to surplus: the hazards of uncontrolled academic growth. Am J Pharm Educ. 2010;74(10):Article 185. doi:10.5688/aj7410185.

25. Carvajal MJ, Popovici I. Pharmacists' wages and salaries: The part-time versus full-time dichotomy. Res Soc Adm Pharm. 2016;12(2):341-346. doi:10.1016/j.sapharm.2015.06.003. 26. Carvajal MJ, Armayor GM. The life-cycle argument: Age as a mediator of pharmacists' earnings. Res Soc Adm Pharm. 2015;11(1):129-133. doi:10.1016/j.sapharm.2014.05.003. 27. Keehan SP, Cuckler GA, Sisko AM, et al. National health expenditure projections, 2014-24: Spending growth faster than recent trends. Health Aff. 2015;34(8):1407-1417. doi:10.1377/hlthaff.2015.0600. 28. Winston C. On the performance of the U.S. transportation system: Caution ahead. J Econ Lit. 2013;51(3):773-824. doi:10.1257/jel.51.3.773. 29. Hamidi S, Ewing R. Landscape and Urban Planning A longitudinal study of changes in urban sprawl between 2000 and 2010 in the United States. Landsc Urban Plan. 2014;128:72-82. doi:10.1016/j.landurbplan.2014.04.021.

30. Chui MA. An elective course in personal finance for health care professionals. Am J Pharm Educ. 2009;73(1).

31. Inflation, consumer prices (annual \%). The World Bank. http:// data.worldbank.org/indicator/FP.CPI.TOTL.ZG?end=2014\&locations = US\&start=2009. Published 2016. Accessed December 4, 2016. 